\title{
NEPAL MEDICAL ASSOCIATION
}

\section{SUPPLEMENT}

A number of Suggestions were received in response to the 1 st draft of the NMA views on the "5 men Committee working paper". These are all printed below but it does not signify that they are necessarily the views of Nepal Medical Association.

\author{
:Hemang Dixit \\ Chairman \\ Policy Making Sub-committee \\ Nepal Medical Association
}

\section{Suggestion No. 1}

1. Brain drain :- To minimise brain drain there should be job satisfaction in the form of generous salary, provision for comfortable accomodation, facility for research, important evaluation of work and noninterferenco by unqualified persons even though he may be in senior administrative post. 
2. Restriction of sale of drug :- Dangerous drugs like Narcotics, antibiotics ete. should be dispensed only on the prescription of qualified doctors. Perhaps it will not be possible at this time to apply in the whole country because of lack of oufficiant number of doctors in Nepal.

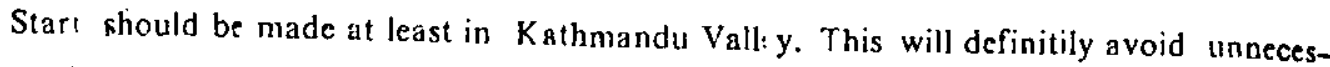
sary complication due to misuse of antibioticr, narcotics etc.

\section{Dr. B.B. VAIDYA}

\section{Suggestion Ko. 2}

Could the local Dhami, Jhankri or Gubaju be converted after basic trajning iuto the projected village health worker.

Re ticket-fees at hospital. Will the hospital Board have control over money collected. Also more involvement of local people in area hospital

Morn attendence at Children Hospital and at M.C.H. projects for preventive measures such as immunisation, regular deworming, advise regards diet. Country wide measles immunisation as it is an important cause of child death.

Special Hospitals. In view of the fact that our country is going to be covered with Raj Margs, one of the hospitals, say at Hetauda could be an Accident Hospital providding special facilities for Road Traffic \& otber accidents with a speciai Ortbopaedic \& plastic Unit.

In this contest there should be also some National Disaster plan as initially envisaged by Dr. Mack of Shanta Bhawan, and later aired at the N.MrA. conference and JNMA. The Red Cross could perhaps be given full charge for this.

Spscial consideration to developing maternity hospitals - at least one in each anchal or even each big town.

Also a Dental Hospital with say two shift of 5 hours to be started in the capiral. Having no inpatient service, of very limited it will be relatively cheap. Mobile dental team under this body.

Like Missions, funds could be solicited from Guthi Sansihan They could be involved in supporting or even running one or two hospital.

Some religious sect (eg. Buddhist) monks or nuns cou'd look after the administrative side of some hospititls supported hy ordinary adequately paid medical and Paramedical staff to work under them. 
In concidering non-practising give a choice to those in service if they want to continue on. Also provision for honorary posts at hospitals or in University appointments for those who want to continue private practice.

Re. wastage of trained manpower. A point fol having a separate administrative cadre rather than transferung trained and unwilling clinicians to administration.

Re Health Manpower. For those wanting to go no restriction re passport once they have finished their bend. Nole likely to come back if tio restriction.

Opinion from Buddhist Organisations on whether monks of ouns would be prepared to undertake traning as A.H.W., A.N.M., Nurse etc. Will produce mure dedicated workers.

Re. outdoor Eitber paying in the evenings only or free rouud the clock. Different set of staff for afterooon outdoor.

In considering rules for service types, of clothes do not apply for doctors \& nurses. Eg Nurses might consider if somethiog like sulwar kurta more practical. For doctors perhaps cap instead of full Nepali dress Opinion of N.M.A. \& Nep. Trained Nuıses. Ass. should be sought.

Healtb Education Full knowleoge to tcenageis others re V. D. and also anvisory Clinics.

Town. etc.

Electric crematorium in major towns.

Control over advertising for tobaccos and alcohal if we are to forestall rapid increase in carcinoms \& cirthosis in future. Limited sale hours of alcohol and ban on sale to minors.

Control over diesel trucks coming to town. Also re. fumes from factories such as brick and cement and dumping of industrial wastes into river.

\section{Suggestion No. 3}

Hemang Dixit

Thank you for sending us the copy of points of discussion on the working paper of the 5 Men working committee held at Siddhi Sadan on 5.6.2031.

As nothing had been mentioned in the draft about $T$. B. we will request you to add the following points to the draft.

1. As regurds the bealth workers, they should be orientated with the Preventive aspect of T.B. once or twice a year. They should also be trained in case finding \& should have basic knowledge on symptomology to find cases. In the draft there is no mention of T.B. control \& its utility.

2. As regards renuneration the staffs working in Tuberculosis Inatitution should be given 
Health Hazard allowances as in other branches of Medicine e.g. Anatsthetists considering the danger of exposure because of constant health hazards.

3. In developing country like ours, sanitorium line of treatment is quite out of thine. Again the cost benefit ratio in terms of Sanitorium treatiment is far more expeusive than domicilliary treatment: In our experience cost involved in one Sanitorium patient will treat at least is to 20 domicjilliary cases.

N. L. MASKEY $\therefore$

S. N. GIRI

N. G. AMATYA

\section{Suggestion No. 4}

Thank you for sending the transcript. The elite sectors of cur nun-medical population are al:o very much interested in this long term bealtb p'anning. Few conments which we heard is that "the doctors are making fantastic plans, but there is no provision in that to the deatbs against their negligence, and that there should te facilittes 'for post-mortem in $\therefore \quad$ We resulting from negligence'. I think this is their logical criticism.

that there faced with this sort of comments very frequently in person and in press. I feel to take up and be provision in the long term planning of a well organised defence Body take und analyse surbib complications.

\section{Suggestion No. 5}

Dr. Suniti Acharya.

\section{Dental Health Service.}

Dontal Health Service bas been Neglected so far in the Health Programme of our it. 4 Five At least, experience shows that a step - motherly treatment bas been. given to it. 4 Five Yea: Plans al-eady have been completed. We are not aware of Dental Programme included in any Five Yeu: Plans to date, except the recent. Dertal Mobile Team. probably insportant is Denta! Health Service as a part of overall Health plan, does not the Dental diaboration. Neverthless a Medical Graduate knows little or nothing about diseases in theses. Even though this is partly the fault of non-inclusion of Dental forget its ime undergraduate currictulum, we should, as a developing country, not in parricula. 
Of the Dental outpatients atteriding Bit Hospital at least lenst

$30 \%$ Suffer from Dental decay.

$70 \%$ from periodontal diseases.

Children constitute - $30 \%$ from Dental decay.

Out of 8,000 Dental cases treated by Dental Mobile team in various parts of the country $20 \%$ suffer from tooth decay.

$80 \%$ from periodontal diseases.

Ne:dless, therefore, it is to say that Dental Heaith Service IS CMPORThivT for the all round Heaith of the country.

The varrous branches of Dentai surgery such as, oral surgery, orthodontics, oprative, prosthoduntics, periodontia, pedodontis elc. do not exist at all in this country.

Regarding Dental Health Service in Nepul, we would tike io place fetw suggestionf before the committee irom Denal Mobile Team, Kanis Hospital.

1. For the next 5 years, the present Dental Dapartment of Bir Hospital mun bs reorganised consisting of various sections so as to make it as a future Dental Hospilat in the country.

2 The location of present Dental Mobile leam should be allached to gur Hospital as a cenire of this organization.

3. In every zonal Huspitals, ove Lental section shoud be created. All Dental sections

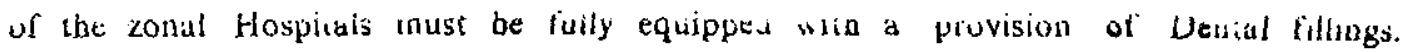
provision snould be ande for ruming Dental Mubite clinies to the nearest distriets ront the respective zorta Hosplats.

4. Lit order to provide Dental Healih service to the people in a counirywide basis, more undergraduates and post graduates scholarships should be avajisble. At least $;$ undergraduates scholarships must be provided evely year in order to create a benul Sectious in every district of the country witinin 20 years.

5. Freshly returned graduat:s in Dental surgery must ve posted in bir slospibal di ismat for 6 month; before they are being sent to zunal Hosplials.

f In every Dental gection of the zonal Hospitals, one Auxitary Healis rorker must of provided.

7. Al tacilities particilarly joctors quartet must be made available 10 the imenta: Doctor working in diffetent zortar Hospitids. 


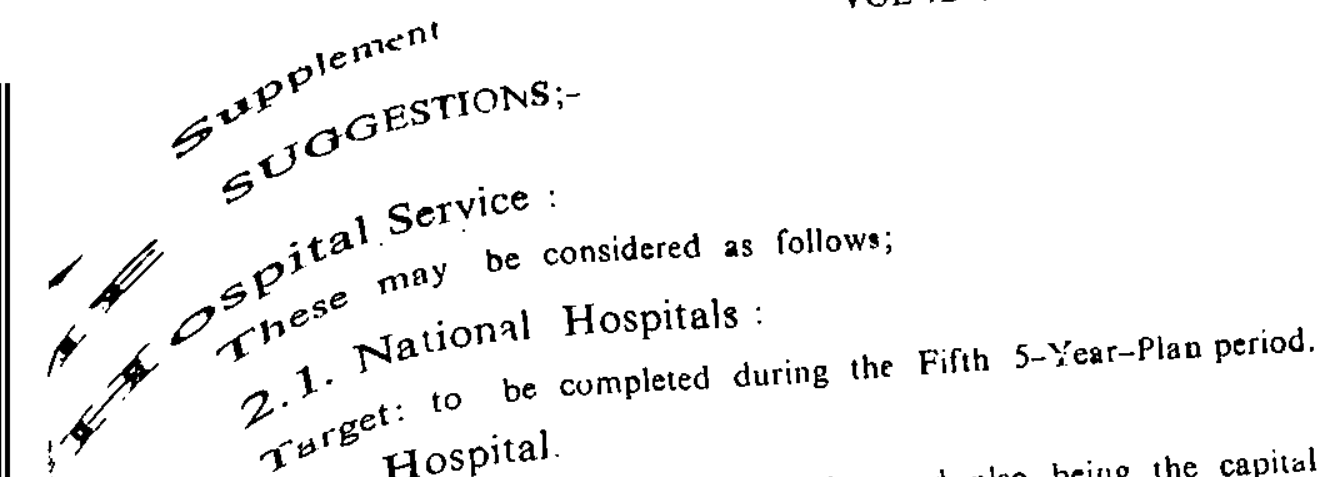

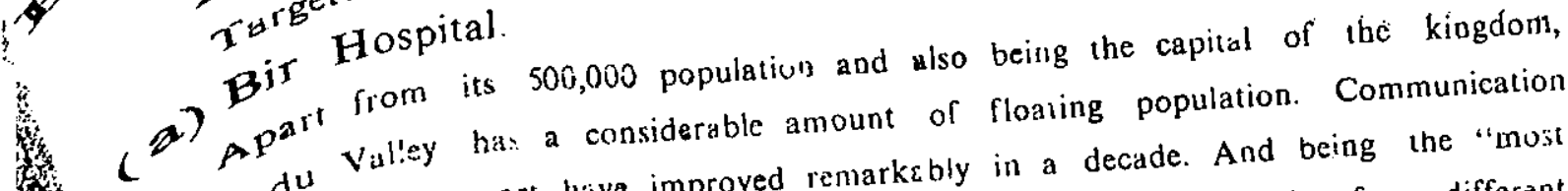
of transport hivo improved renarkebly in a decade. And being the "must staffed premier hospital of the entire country", sick people from different country tend to flock the Bir Hospital-in fact $50 \%$ of the hospital come itrom oulside the valley. Thus a siguficant, amount of money is spilling into India whero previously people used to go for their medical Fresh Medical Graduates ten: to flock the Bir Hospital because it is the moment to learn some amount of practical Medicine for whatever it is worth. ot the mom them elsewhete in the country, His Majesty's Government should make it a Hife postiog them t-Year INTERNSHIP TRA.NING in Bir Ife for for $^{e}$ these young graduates to ofer Thic and other hospitals of National tovel

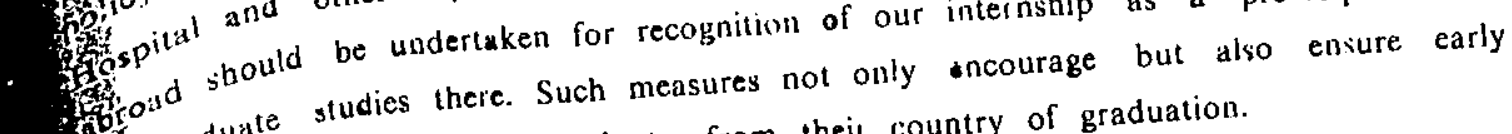
Hograduate studias of the fresh medical graduates from theil country of graduation.

7f $x_{\text {(b) }}$ Infectious Diseases Hospital

Hef There will probably be no second opinion ab ut the importance of control of Hemmunicable Diseases and therefore of the Infections Diseases Hospital. Most of the Pfiseses of the country are of this category and it is but natural that some sort of Hitution has got to come forward to tackle the problem. Infections Disease Unit of the Bir 4 Fospital is just the place wbere this ought to sturt from.

IX At the moment working in 1.D.U. is far from satisfactory. If we are to serve the Hengly poor patients properly, we need to improve the facilities so as to approach the Ho criteria. In olher words, this means converting the present hospical into a HUCLEUS FOR THE CONTROL OF COMMUNICABLE DISEASES for the whole 4 tingdom of Nepal, for the simple reason that more than half of the lotal inpatients 潅 
8. Provision should be mado to create and train Dental assistant from Auxillary Healtb worker and A.N.M.

9. Dental proft-ssion must be either included in Medical Health service or Dental Health service of H.M.G. of Nepal.

10. We hear much about the formation of various facultics in medicino EXCEPT THB DBNTA FACULTY which should bave its due place.

Dr. Mesh Bahadur

Dr. Manik Ratna

\section{Suggestion Ho. 6 *}

"HEALTH!IS A FUNDAMENTAL HUMAN RIGHT, BUT IT HAS TO BE WON ..." 1. There Must Be A Plan :

Till 1950 Health Department was considered to be an institution for charity rather then a fighting-ground for securing health for the country. The idea now has changed so that Mdical Services are looked upon as a basic necessity for the people. Several attempts have therefore been made- the Fourth 5 Year-Plan is at its end now-to find out ways and means for the improvement of the health of the country, by the Directorate of Health Servires, which has however failed to deliver the goods satisfactorily so far, probably because the Plan has been rogarded as a document of utmost secrecy. Since a PLAN CELL has come to exist now in the Dept- Ministry of Health. one bopes that it will function efficiently. An ADVISORY COMMITTEE of experts, if formed, may be able to guide the Pian Cell as and when necessary. Meanwhie, the attempt by the Hon ble Minister of Healtb to formulate a Health Plan based on the field-study by the nominated 5-member Working Commilice outside the Dept. of Health Services is pratiseworthy indeed. One hopes that this Commiriee may produce a realistic plan with clear objectives and practical methods of implementation for the successful altainment of goals--as a part of National Plav i.c. Fifth 5-Year Plan. However, is mentioned already, an ADVISORY COMMITTEE consistiıg of experts from all the branches of Medicine is a MUST to guine the Plan Cell.

* Originally pubtished in the Desera issue of KAMJHAM. Reproduced with thank: with permission from the Editut. 


\section{(f) Psychiatric Hospital:}

HMG is understood to have acquired sufficient land for it. The Fifth 5-year Plan should see its completion so that the patients may not have to wait any longer.

(g) Medical College:

If the above hospitals of NATIONAL LEVEL are upgraded during the Fifth 5 year Plan-period, there is no resison why a Medical College should not come into the picture. As the fact of the matter the National Hospitals from the basis for the Teaching Institute Moreover, Nepal bas got adequate technical personnel for this. In lact first year medical students can be taken even in the beginning of the Fifth 5-year Plan.

(h) School of Nursing:

A paradox of more doctoss and far fewer nurses is the rule at present. To run the hospital services more efficiently, nurses sbould be 4 times the number of doctors. Naturally, therefore, the training programme has got to be ruultiplied to a great extent HMG may make it a rule to post nurses at their home town or districts in addition to their pay-rise besides otber facilities-to attract more girls to nursing profession

\subsection{Zonal / Anchal Hospitals:}

Target: to be achieved in the Fifth 5-year Plan-period.

During the first year of the Plan-the hospital stoould $b$ ingraded to 100 beded one from the present state of 50 beds.

During the rest 4 year of the Plan-the bed-strength should go up to 250 .

This may appear to be rather optimistic. But if we consider the following, the validity of the argument will be justified: There are a number of Zonal Hospitals spreading right across the lerigth of the country, starting from Bberi Anchal to Koshi Anchal, the Zonal Hospitals being placed at Nepalgunj, Butwal, Birgunj, Biratnaga! etc. The Lumbini Zone, for example, has three 6 hospitals at Bhairawa, Butwal and Paipa, the total bed-strengtb being about 100. All "these "units" can be combined in a single Zonal Hospital--the site being decided following field survey. This NEW Hospital can be run by the pooled technical staff, including the administrative staff, of all the "units" Each "unit' then works as an OUTPATIENT \& EMERGENCY DF"ARTMENT of the new Zonal Hospital. The outpatient dept. will.be cun by the specialists from the NEW Hospital--they will be visitiug it thrice weekly in the beginning and later every disy in the course of 5 years.

The advantage is this-that no extra budget is involved; communication and 

of the hospitals of Nepal do fall in the list of infectious diseases, and their complica.
tions.

We can learn from our neighbouring country India in this regard. She has already established inatitutes such as INSTITUTE COMMUNICABLE DISEASES. The problcm of communicable diseases is taken up by the Institute in collaboration with the area areas concerned: investigations are carried out, results analysed, ways and means are formulated and the problens are solved scientifically.

Since our various PILOT PROJECTS (Malaria, Smallpox etc.) are goins to be closed down soon, there is all the more urgency for setting up an INSTITUTE of COMMUNICABLE DISEASES, the hospital forming the laboratory, in the very near future. This will help to institutionalise our problems of communicable disesses.

(c) Chiltren's Hospital :

This is the only Children's Hospital in the whole country where the tolal childhood population (L-16 years) is about 5 millions, i. c. $50 \%$ of the tota! population of the country. IMR (Infant Mortality Rate) is about 244/1000 live-births-compare it with that of U. K. where IMR in 1962 was $22 / 1000$. The total death in the age-group 0-14 years is greater than the total death in the age-group 15-60 years and above-about 4 times more deaths occur in the age-group 0-4 years than in the age-group 5-14 years. Doctors practising in Nepal therefore have got to know the diagnosic and treatment of Childrer's Diseases. What place will be tnore fitting than the present Childreil's Houpital? Naturally, therefore, this bospital needs upgrading and a courso of time, say 10 years, this should te changed into an INSTITUTE OF CHILD HEALTH. Meanwhile HMG should be congratulated for contemplating to increase its bed-strength 10150 beds during the coming Fifth 5 Year Plan. It would however bave been more appropriate, bearing in mind the urgency of the necessity, if the beds were increased to 150 in the first 2 years and upto 250 beds at the end of the Plan-period.

(d) Maternity Hospital:

This hospital at Thapathali shows how voluntary organisation can work for the people. At thie moment it has a bed-strength of abut 100. This can be enlarged to 250 beds in next 5-year Plan-period.

(e) Eye Hospital:

A start has already been made on a voluntary contribution basis HMG should encourag it and make it at least a 100 beded hospital. We have people 10 run it
efficiently. 
means of transport are good in the area so that if an AMBULANCE SERVICE be avalable, there is no reason wby this should pot work properly. Actually the UNITED MISSION HOSPITAL at Palpa has been running outpatient service al Bhairawa and inpatient service at Palpa since many years One wonders why this cannot be done by the "brave" Nepalis during the first year ar so of the Fifib 5-year Plan.

During the remaining 4 years, this Hospital shiruld be enlarged to 250 beds.

Likewise, similar steps can very well be taken for KOSHI. ZONE HOSPITAL by pooling the resources of Biratnagar, Jhapa, Inerwa and Dharain hosp:tals and similarly in NARAYANI ZONE HOSPITAL by combining Hetaunda. Bhimphedi, Bharatpur and Birguni hospitals.

In the second phase $i c$. by the end of tine Fifth 5-year Plan period, HMG should be able to supply requisite number of specialists to the ZON.4L HOSPIT:IL. This means that the Health Directorate should have its Training Section fully geared to the situation.

This will solve the problem of (a) offering rostgraduate trainiag to those who deserve and (b) the constant headache of promotion, transfer etc. of the Depa $t-$ ment

\subsection{District Hospitals.:}

During the Fifth 5-year Plan the bospital runs outpatient service and emergency service only, and also attends to the cases referred to it by the Healih Post or Health Centre. Those needing inpatient care will be Iransferred to the Zunal Hospital netrby. Specialists from the Zonal Hospital will attend the outpatients regularly.

During the Sixth 5-year Plan period, the inpatients will be taken in to reach the figure of 50.

\section{Basic Health Service:}

The concept of supplying VILLAGE HEALTH WORKER AT THE PANCHAYAT LEVEL as planned by HMG is praiseworthy indeed. According to the Plan, 810 Health Posts are expected to be filled by the end of Fifth 5-year Plan. In addition to the service of the people at the village level, this will provide us with the much needed information regarding the basic health statistics of the country.

\section{Public Health Service:}

This is so important that HMG should try to devote more time and budget to this. 
This beromes all the more important in a developing country like ours. We do not know what is PERSONAL HYGIENE for which HEALTH EDUCATION SECTION should be more active: INTRJDUCTION OF HEALTH MATTER AT THE PRIMARY SCHOOL LEVEL-which is being done by the Ministry of Ejucation-and co-operation with the Ministry of Food and Home Affairs for introducing suitable LAWS REGARDING FOOD HYGIENE, regulations regarding SLAUGHTERHOUSE, TRAFFIC LAWS (for example a Symposium on Traffic Accidents), etc. are called for. We do not seem to have SAFE DRINKING WATER. HMG can work with the Ministry of Water \& Power for this. Also we do not have scientific methods of D'SPOSAL OF SEW $\triangle G$, which could prevent epidemice of Cholera, Typboid fever, infective Hepatitis. Poliomyelitis and so on. Again, to make the matter worie, we do not have legal provisions regarding DRUGS,excepting a few dangerous drugs, there is absolutely no restriction against the sale of antibiotics, stimulants, hypnotics, insecticides etc.Any persons can practise medicine with absolute isomunity and impunity, as a result of which QUACKS flourish like mushrooms. So long as there is lack of sufficient number of medical practitioners, it must be admitted, this is bound to be so. However, appropriate LAWS CONCERNING MEDICAL PRACTICE should be introduced in collaboration with the MEDICAL COUNCIL.

\section{Administration:}

Probably these will be no second opinion regarding the necessity of (i) Organization Chart (ii) Job description of the personnet, (iii) Evaluation system, (iv) Regular promotion and (v) System of Reward and punishment.

Another problem-bow much power the Director of Health Services ought to wield ? He should probably have complete control of Basic Health Service, Public Health Service, Medicinal supply, some control on the various Pilot Projects probably mainly as a coordinator or integrator of the overall health-services of the country; he should also partially finance the Hospital Service. The Hospital Services should preferably be under the control of the HOSPITAL MANAGAMENT COMMITTEE consisting of proininent public persons, social workers representative of the local hospital doctors, Zonal Administrator and a representative of the Directorate.

Having said that, there is always a prohlem as to who is the best candidate to fil] the post of Director of Health Services. Clinical excellence does not necessarily mean administrative excellence--in general, probably doctors do not make good administrators. Nevertheless there is always someone who rany readily disprove this theory. 


\section{SUGGESTJON. HO 7}

Dear Doctor Dixit,

I have not received my copy of the paper you have circulated giving points of discustion on the fifteen days' working paper submitted by the 5-Doctor. Task Gorce. However I have recently read. Dr. D.N. Regmi's copy. As according to the general notice posted at Bir Hospital the meeting beld at Siddi Sadhan on Saturday 5th Aswin was to be atiended by- all the doctors in Nepal whether members or non members of the Association and as I had attenect this meeting as a non member, I would for the sake of record like my name to be completely dissociated from certajn remarks in your paper as quoted below.

1. Para :- "When the Health Posts are manged by Dectors then possibly. the village Health Workers could be supervised by him regarding curative Ireatment. Until then ne control over medicine".

Comment :- By definition Health Post is a rural health institution which will not be staffed by doctors. Also the idea that rural herth in Nepal requires that the village health workers need supervision by Doctors concerning control over medicines and concerning curative treatment is unrealistic.

2. Para ;- "The concept of regional hospital should. be such that they' stiould be in areas where they are most needed i.e. concept' of hospitals' should be on population basis and not as a political expédiéncy $y^{\prime \prime}$.

Comment :- Here probably the reference to Régitonal: Hospitals häs been an error and a district hospital was in fact meant if wo are to make much of the latter part of the sentence that Concept of hospitals should be on population basis and not as a political expendiency otherwise one cannot make sense of the implication that a Regional hospital is not likely to be in an area where it is or will be most need:d and is convenient for the population of the Developument Region. The quiestion of political expendieney deserves a fuller treatment with examplés, otherwise itś casüal mention in paper concesning a discussion on the work of a Task Force to develop a proper plan of the healih care delivery system for Nepal in the near and distant future, is likely to be misleading

3. Para ;- "These should perhaps be a 'Flying Doctor' service if need be under the careof the Army Medical corps. Govt prsonnel including dostors. serving the outskirts should be in , regular contact with theit regional centre and their feeling blostered up 
in the sense that: they are aware: that the event- of unfortunate, circumstances inmediate belp will be forthcoming",

Comment :- I' would have thought that the purpose of this remark was exactly what the Govt. had in mind in deccotr alising health facilities to the Development Regions and" in trying to provide hospitals in all health districts of Nepal, so that both the people inhabiting a particular area as well. as Government Officials serving in that area could avail of the treatment, if they were unfortunate eoough to fall ill. The development of these facilities in the mountain and billy regions of Nepal also and the trend towarus establishment of medical care units in the high altitude regions under the initiative of H:M.G: and the Himalayan Rescus Association (of which I had the hnnour of being a founder member), are also meant to achieve the same objectives.

4: "There should be three categories of health staff: 1. Administrativo 2. Public health

3. Clinical (curative)" ".

Comment:- Firstly Doctors are not the only health staff of Nepal. Secondly, concerning the catagory of administrative health staff - if a doctor is only to administer the heaith services, should he undergo courses of training in the usual aspects of medicine as an undergraduate and only in them and after qualifying should he or should be not work in the clinical and the preventive health service areas. Thirdly Public Health means health of the public, that is health of the nation. It indludes all aspects of health care delivery for the nation and is not limited to health care under the public sector only. The posts of Public Health Nurse or Public Health Administrator if they are meant only for Nurses working outside the hospitals or administrators concered only with preventive health services, would be misnomers. Public Healih includes medical care (also called Curative Health Services) and preventive bealth șervices. $\wedge$. Ministry of Healtb is actually a Ministry of Public Health. Plans for Govt. spending on National Health as well as the health pattern in the Country outside the Govt. sec'or should be taken into account when making health plans for the country. Fourthly, while Preventive Health Services reduce health needs of the people by primary preventive measurcs, diagnosis of certain clinical conditions is secondary prevention and treatment of certain clinical conditions may turn out to be tertiary prevention. Therefor is case of communicable diseasea for instance clinical includes botb medical and nursing care as well as the preventive health services.

5. Para :- "What is happening at Bara and Kaski should be the rule and not the 


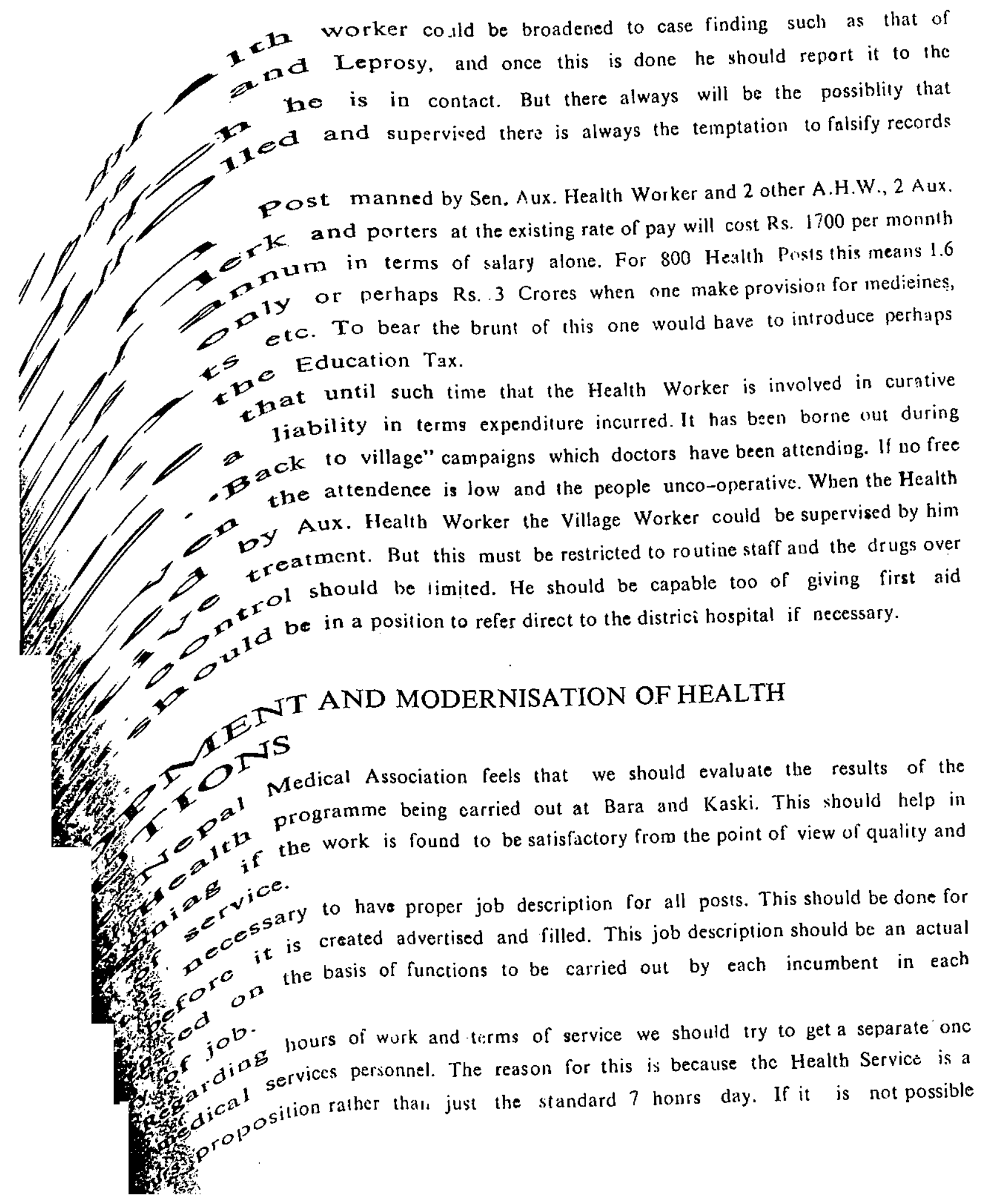


J. Nep. Med. Asp. (1974) 12-5 \&6

\section{PROPOSED N. M. A. REPORT. NO. 2}

\section{BASIC HEALTH SERVICBS FOR NEPAL.}

The Nepal Medical Association agrees with the concept of providing medical and health care to the maxim.m number of penple, ultimately covering the whole population
of the country.

This idea of the village Health Worker is praisewortby especially in view of the faet that it will provide the basis for any vital statistics in the country. It is better that his orientation should be more in proventive aspeot then on the curative one, at the initial stage at least. Ho would be given adequate facilities, not only regards pay but could be utilised. The Provision for promotion oto. Perbaps social workers, or retired pensioners -wn work and further Pancha. It would probably be eer to recruit local personnel for this even on a Dhami or Jhankri can be placed after basic training The cost involved however would. Training of these people should be properly done. estimate of Rs 2000 per year per village worker arge even when one takes a reasonable ter at a basic rate of Rs. 150 per montb. This u the srea to be covered is laf 90 Lakhs or approx Rs. One crore, Furthermore panchayat. The question is how it might bo necessary to have more than one per wolfare.

The village health worker is in contact with a Healtb Post-Ratio of 810 Health Post to about 4500 village panchayats would be 1.5 roughly. The worker should bo supervised by the senior Auxilary Health worker of the Health post. In later years the 
then a separate code for the medical services within the existing framework of the civil Service Code should be establisined. There should be some time \& motion studies to check that existing staff are not overworked and that the medical services provided by them does not deteriorate.

There should increased remuneration for Junior medical and otber staff. The Anaesthetists, and other specialists not haviug additional income from private practice should get a higher scale of salary. It is necessary to increase numbers of not oniy medicul staff but also para-medical personnel proportionately. There should provision at the Health Posts and hospitals to ensure that the service provided to the people does not suffer by virtuc of the fact that the concerned individual is sick, away on leave or just on deputation. What happens when the single surgeon has an attack of appendicitis? Facilities for residence and also extra pay for extra work should be provided. Reserve personnel should be arranged for immediate replacement when and where required. This applies more so in cases of leave for people working in outskirts. Leave must be sanctioned when due on when they need it.

The concept of regioal hospital should be such that they should be $i$.1 areas whers they are most needed that is concept of hospitals should be on population basis and not as a political expediency. There should be at least 200 beds, but until sucb time as there regional hospitals are functioning, specialist service should continue to be provided at the existing 50 beded zonal hospitals. Later on, one can man the 50 beded zonal hospitals with general practitioner type of doctor. When such a step is however taken there $m$ ist be some criteria for selection to theso posts and there should also be chances for further promotion and advancement. In short it must not be a 'dead-end'. Inducements should be effered to encourage doctors to lake up general practice and help should be given to sel up clinics in specifed areas. Doctors functioning as specialists must be discouraged from working as a G.P. at the same time.

To lessen the burden on the Govt. further sources of revenue sbould be tapped, eg. from Guthi Sansthan as is being done for the eye Hospital. The Ramghat Health Centre could be converted into a small hospital, in view of its important situation and be called Pashupatinath Hospital the change for supporting it will be the Guthi at Pashupati. Similar:y the Janakpur Hospital could be supported to a g reater extent by the Janaki Temple Guthi. Private, Semi Government and non profit organizations should be influenced and encouraged to share the burdens of expenditure to help the Government. The Regional and 
or zonal Hospitals should be set up under a Board of Management which will explore local sources of income. Similarly institutions such as Tokba Sanatorium which is un anachronism should be closed down or converted for other purposes.

Some religious sects (eg. Buddhists) monks or nuns could look alter the administrative sije of some hospitals supported by ordinary atequately paid medical or paranedical staff to work under them. Opinion could also be got whether monks or nuns would be prepared to undertake training as A.H.W. or A.N.M. Nurse etc. Will produce more dedicalted workers.

However people in areas such as Mugu and Jumla should not neglicled for they 100 like the rest of the country must bave facilities for healuh. The Goveinment must remember that the bealth service is not an industry which gives a direct return on the investment. There should perhaps be a 'Flying Doctors, service if needed under the case of the Army Medical Corps. Govt. personnel, doctors, serving in the out skirts should be in regular contact with their resional centre and their feeling bolstered un in the sense that they are aware that in the event of unlortunate circumstances, immediate help will be forthcoming. There should be system of feed back.

Paying concept can be introduced to the population by charging a very nominal amount eg. 25 pice for O.P.D. tickets. This will help hospital funds and may also curtail unnecessary visits to the hospital. For after all 'free' services are not respecled by the people. On the other hand it must be remembered that this 'fee for service system' prevents the group most in need from utilising the survice. Evening clinics can also be started at the hospital. The fee charged will be say 10-15\% less per persons than that charged at the private clinics and the money so will be shared by the hospital providing the facilities, the doctors using them and the pari-medical staff doing extra duty at this time. Alternatively the hospital O.P.D. could be let out to doctors wanting to use them during evening hours.

Amount of food supplied to patients should also be reviewed. Perhaps some sort of arrangement as at the Trisuli Hospital.- Providing only to these in dire need will be less costly to the state. Perhaps a canteen in bigger hospitals and cooking facilities and sheds in rural ones will solve this problem to some extent.

The National Referal Hospital should be started within the next five years and completed within ten. Referred cases coming here from outside should be immadiately seen or admitted. As all posts there will be non practising, adequate remuneration should be 
The fact that there is no Sirgival Dept. is an anomaly which must be immediately rectified. Having just medical beds does not constitute a childrens hospital. These should also be facilities for isolation and a gastroenteritis ward cum rehydration centre is essential considering the number of children who require immediate treatment.

The investment on health services for women and chidren will pav in the long run for it will ensure a healthy nation in the future. Illness in both these groups consists not so much of a chronic type but the acute or one which tends to clear up in a matter of days. . The slogan should therefore be 'Women and children first. The ascent again should be more on preventive than curative medicine. Proper autenatal and post-natal facilities for women, proper immunisation, supervision and care of children in special well baby clinics until the age of 5 years should be ensured. These clinics should bean integral part of the hospital and should be run as such: To get a better and wider coverage it is necessary to get the A.H.W. and A.N.M. to sort out the routine stuff. The doctor, relieved of the routine stuff, will be better utjlised seeing the special cases and atso teaching his staff. This consept must be applied to all the hospitals in the cotntry and not be restricted to the capital.

The contemplated single hospital for women in the capital does not take into account the occurance of extringencies such as tetanus infection in the labour room. operation theatre or ward. It is therefore necessary to have at least two centres in the capital. On top of all this, there should perhaps be a similar hospital in the other Regional centers, besides there being some maternity beds in each on the hospitals of the country. Perhaps help of voluntay organisations can be elicited for this, as at the Prasuti Griha in the capital. More stress should be laid on training of Nurse-midwife, for home deliveries by A.N.M. will be less costly to the state. A.N. Midwife should be trained in much larger number if there is to be any marked impact on these services and the subsequent reduction in infant mortality rate.

All the Regional and Zonal or District hospital should provide dental facilities. There should also be a separete Dental centre in the capital providing a minimal inpatient service-perhaps attached to the National Referal Hospital. The complicated and time consuming cases should be seen here rather than at the other hospital dental depts, where quick service would be necessary. The various branches of dental surgery such as oral surgert, orthodentia, operative, prosthodentia peridontia, pododentia, would be done here. 
paid to the doctors. Hesides saving money which would go to hospitals in India such time as a National Referal Hospital is formed, a Valley Group of Hospitals should perhaps be started with Bir Hospital, Patan Hospital, Bhaklapur Hospital, Kanti Hospital, Prasuli Griha, Surya Binayk Hospital and the Infectious Diseases Unit.

Such a grouping can for the time being function and be hosp:tul in the near future. As the contemplated National Hosplat basis for any teaching take substantial amount of the yearly budget teacking hospital should not only train doctor this is perhaps the better alternative. Such a that in dev.loping countries these type of Refers but whole Health Team. The other point is generally beseiged by large number of Referal Hospital fail in their function for they are connection with the Infection. Desease patients-many with preventable conditions. In uncleus for the control of Infectious Direase unit it should perhaps be converted into a more than $50 \%$ are due to Infectious for in Nepal, of the hospital in patients, Apart from the

yet another General Hospital in the apitasital there should be, besides the Bir Hospital, spirrit in the institution and thus impros will tend to impart a feeling of competitive organisation such as the Nepali Marwaine the standard of treatment. Perbaps some With their financial help and provision of Hospital (Cl. Italian Spanish Hospital In London). hospital, facilities will increase in then of staff, as at the prasuti Griha, by the Government

The argument that Kanti

With the new Ring Road, the town is is too far a hospital for the town does not hold. If the service provided is of high is expanding outward and also in Northerly direction. seciion of Kathmandu goes to shanta Bhaw, people will come there jnst as a certain $40 \%$ of the population is under the age 14 Hospital. Keeping in view the fact that increase as infant mortality rates decrease, 14 years and that this percentage is going to Hospital's capacity to at least 200 teds, it is obvious that besides increasing Kant of hospital beds in the country for the carought should be given to alloting at least $25 \%$ regions. should have a 50 beded children. Perhaps each of the olher tbree more on the older age group ic. those whospital. Unfortunately the tendency is to spend be to greater expenditure preventive aspects in the less of life in front of them. Shift should Besides the Dental facilities whichs in the earlier years of life. be provision for once or bi-wes which necessary in any children Hospital there should 
trained and unwilling clinicians into administration.

Only limited top posts (which must the clearly defined) should be no non-practising, provided of course that the Govt. is prepared to give a reasonable scale of remuneration. The other posts should be practising, for after all people will continue to become ill. And if not many doctors are practising, it will mean that medical practise as such will go into the hands of quacks.

\section{EFFECIENT AND EFFECTIVE HEALTH SERVICES}

The Nepal Medical Association feels that though the Mnistry of Health is concined. with policy mattes and the Directorate with its execution, this very arrangement has ted to a state of aliairs where there is a tendency to too much segregaumin. I laere should os a regional sei-up of four Keyional Directors controlicd by the Hitalili secretaly, who mus be a medical graduate with post graduate training in technoues of Administration of Management. With the advent of the various plans. eg. Country Heaith plan, 20 years l'lan, Fifth Five Year Plan, and the Five men Commission tlan $1^{2}$ is higit time that the rLAN CELL in the Ministry of Healtu got down to work to evaluate and make what should be a Master Plan, suited to the needs of the country and with aims which are altainable.

In each of the regional sot-ups, integration should be carried out in practise and not in theory only. Having five tablets in one room does not constitute integration. What is happeniug at Bara and Kaski should be the g'tiding force and not the rule until such time that a proper analysis condirms it to be worthwhile. What is happening there must be applied all over the country if the service has quality within the next ten years. The question is whether the performan:es in the two districts can be guarenteed to be ool proof and can be reproduced elsewhere when spotlight of the W.H.O. and others is no longer on it.

To regularise the matter of supplies to not only outlying districts but also to the regional centres it is necessary to have a Central Delivery Unit of H.M.G. of Nepal. The Unit would serve all the ministries and departments such as Healih, Education, Panchayat etc.

There should be facilities for post-mortem in cases where negligence is insiruated and even in all all patients dying within 24 hours of adminission to hospital. A good forensic laboratory must be set up in view of the increasing number of unnatural deaths due to accident or foul play.

Like its education counterpart, it is necessary to have a high powered Advisory Health Committee. It would consist of experts from all branches of medicaine. 
The Central mobile teams would be under this central body as also the charge of managing Dental Camps in different parts of the country. Dental hyienists will be trained at this centre as well. Similarly the Regional and zonal hospitals will have mobile units attached to them. In order to provide country wide dental services more under and post graduates should be trained. Similary there must be provision to train dental Assistants from Auxilliary Health Workers on A.N.M.

In Health Planning in Nepal there must be emphasis laid on the prevention and care of tuberculosis under a National Tuberculosis Control Programme. This is necessary in view of the high prevalence of tuberculosis in town dwellers and high susceptibility of the rural dwellers who take up abode in urban areas. There should be stress on the preventive aspects viz health education of all and mass immunisation of children between o-14 years. Diagnosis and treatment of tuberculosis should be possible to very peripheral level to bring them as close to the patients house as possible. This can also be done by para-medical personnel by means of sputum smear for it is the cheapest and most practicable method which can be done on a country-wide baris. With the establishment of other Chest Clinics, treatment by and large should be on a domiciliary bases. Sanatorium treatment is out of date and the cost involved for one patient will treat at 18 to 20 domiciliary cases. Alternatively the budget available for sanatorium beds should be used for treating emergencies such as profuse bleeding cases or gravely ill patients. As in otber fields of health, help from voluntary agencies eg. Nepal T.B. Association should be encouraged provided it fits into the National T,B. Programme. As the disease is highly infectious, the workers in this disease are always exposed to the high risk of being infected. Hence workers in this disease should be given adequate allowances and if they are unorftunate onough to be infected, then it would be obligatory upon the institution to see that they are well cared for.

In view of the fact that our country is going to be covered with Raj Marga, one of the Hospital should be an Accident Hospital providing special faciltties for road trafic and other accidents with a special orthopaedic and plastic unit.

There should be three categories of Health Staff :-

i) Administrative.

ii) Preventive.

iii) Clinical (Curative).

There is a point for having a seperate administrative cadre rather than transfering 
post nurses at their home towns or districts in addition to their pay rise and other facilities to attract more girls to the nursing professions.

The Nepal Medical Association feels very such let fown by the attitude of the Govt. to the doctors. The Rs.7/- clinic fee ceilling for Govt. services doctors, broadcast over the radio in such tones as to suggest that doctor; were anti-social elements was not right. The same thing could have been done by serving each Govt. doctors a notice. Once the Rs.7/-ceiling had been promulgated the Nepal Medical Association welcomed it thinking that in this inflation ridden age, this was the first step towards stapilising prices, But what happened--no other section of the community had any steps taken against them. Stopping the recently qualified doctors from working at the medical balls bas resulted in para-medical personnel and persons who are not even that, practising unchecked. The poor people who still are being exammed free at the medical halls are not getting a fatir deal. The Nepal Medical Council bas not taken up ibis point of medica. practise by unqualified persons. Furtnermore qualified or ever unqualified persons come to Nepal from time to time, advertise in no less a medium than the leading Daily Newspaper, see patients and needless to say leave witl pochets bulging with wards of notes. To such an event the Nepal Medical Council and the Income Tax authorities seem to turn a blind cye whilst the Gorkhapalra Corporation, getting its share of advertising reveue could not care less.

The Nepal Medical Association feels therefore that the Govt. should stop practise of any sort from the Chemist shops, introduce 'Paying' evening clinics at government hospitals at a rate approx $10-15 \%$ less than at private clinics per person: allow and encourage Junior doctors to start clinics in various areas of any town and charge Rs. 10/per consultation at their private clinits. To make sure th $t$ poople do go to these clinics it is necessary that doctors qualified for more than 10 years or as sp:cialists should be allowed charge a! least Rs. 15 and doclors working as consultants should be allowed to charge at least Rs. 20. Failing this the Junior doctors should be allowed to charge $\mathrm{ks}$. 10 and for the others there should be a floating malc. This is necessary for during lae last twn years there probably has been an yearly inflation rate of at leasi $15-20 \%$. It is not only petrol which has gone up $150 \%$ but commodities such as rice, milk, soap. oil ard meat have gone up in price In 1974 therefore, after having paid rent for the premises, deducted regulitr expenses such as linen, rubber gloves cic. the Ks.7/- private clinic charge is nut of date Not only that - the Rs.7/- specialist cinic is still too expensive for the 
There should be a good medical and statistics department. To get the NMA Supplement? of the country it should be made compulsory to report and record births masic statistics: deaths in each panchayat on ward. The notification of nort and record births, marriages and bility of the village Health worker. aegis of the future Medical College or under the Nepal Medieal Association at its headquarters
at Siddhi Sadan.

\section{HEALTH MAN POWER.}

The Nepal Medical Association has been saying down the years that the Medica College is must for the country. For its proper functioning a number of the top posts nust be non-practising but the remuneration paid to the doctors should be generous
enough.

A lot has been voiced over the years regarding the so called Brain Drain'. It is a fact of life that in any country of the world there will always be some people who ate not stisfied Govt. should allow them to go. Education levided that they have finished their bond, the and passport should be given. Having furthered their anctioned without any hesitation study they will probably come back, or failing that at aims regarding further training and foreign exchange to their kith and kin back home at least remit a substantial amount of but main concern should be with the drift of doction a developing country such as Nepal than doctors leaving the country. There should be more encouragem areas to the cities rather in rural areas - such as additional pay, tax relief, good housing and help of preference in schooling for children and a and above all proper facilities for work.

As already noted above there should be fixed rules and regulio

transfer and chance for further study. There should rules and regulation for promotion, evaluation of work and non-intrference by unqualified be facility for research importent a higher administrative post. There should $b_{e}$ specific persons even though he may be in albeit within the existing Civil service code. The Health for people in Health Servicesecogised as a team and not on individual professional basis.

This brings one to the question

vorkers such as A.H.W. etc. This applies more so in the case of nurses ahd others para medical ir geater numbers of the hospital services are to improve 
NMA Supplement

counterpart Royal Drugs Ltd., should be able to met their requirements. They should be encouraged to take up research in this trom of medical treatment - so that uotimately they will be in a position to provide a modest and less expensive from medical treatment, suited to the needs of the country.

Reference:-

N.M.A. Report No. 1 - Medicine \& Medical Practice in Nepal.

Conf. Souvienir - 1973.

The final report will be made from this proposed paper and handed over

to the appropriate authorities.

N.M.A. Policy Making Sub-Committee:

Dr. Bhasker Sharma.

Dr. Rita Thapa.

Dr. Jwala R. Pandey.

Dr. S.P. Bhattarai.

Dr. Kalyan M. Dixit.

Dr. T.B. Khatry.

Dr. Madan P. Upaddaya

Dr. Triratoa M. Tuladhar.

Chairman: Dr. Hemang Dixit. 
really poor man and too cheap for the hypocbondriacal will-todo who make it a practice and subsequently buy perhaps one item frome varous prescriprions, they on their own chose.

It is absolutely aecessary to reduce the price

of view, he will get is at a chary to reduce the price of drugs. From the patient's point pharmaceutical houses at the special bospiat hospital procures the drugs from the ital and then sells it to the patient at a prescribed by para medical basis. Whilst basic antibiotics and other drugs souid be dishenses on a doctors prescriptionnel, norcotics and dangerous dr"gs should be only and other Nagar Panchayats.

\section{INTERPRETATION OF HEALTH PROGRAMME FROM} INTERSECTORAL VIEW POINT.

Publicity on farmly planoing can be encouraged on the wireless but there must be certain rentuictions on advertising by the tobacco indusiry. Similarly there should be some restriction of sait of iatoxicationg beverages to minors and also limited hours of sale. Instruction shoula be given to teenagers and other re V. D. and also advisory
clinics.

Steps should be taken to improve environmetal sanitation, emphasis on proper sewage and garbege disposal and improvement of water supply. Of this the most important financial support but they should beheld responsible for any shortconings. Similarly there severely penalised to discourage to preven adulteration of foodstuffs and offenders must be major towns. Also shoctices. There should be electric crematorium in rivers.

There should be some National Disaster plan contemplated at the time of the 6th. All Nepal Medical Conference. The Red Cross should perbaps be made to take
charge of such a project.

Last but not least. whilst the Govt. is encouraging the training of Ayurvedic practitioners and also setting up Ayurvedic dispensaries, it should at this initial stage take percaution to see that Ayurvedic practitioners do not function with the aid of sophisticate modern expensive drugs. The existing Singha Durbar Baidya Khana like its 